\title{
MEASURING STUDENTS' MEMORABLE CONFERENCE EXPERIENCE AND BEHAVIOURAL INTENTIONS
}

\author{
Dora Rašan \\ Marina Laškarin Ažić
}

https://doi.org//10.20867/tosee.06.44

\begin{abstract}
Purpose - Hosting conferences has always been of crucial importance for the development of the pre and post-seasons of some destinations in Croatia. Considering that students are becoming the most frequent conference participants, the authors recognized the need to measure their memorable conference experience (MCE).

Methodology - To this aim, a questionnaire was created, based on the relevant scientific literature, and distributed online and onsite. Research was conducted among 108 students of the Faculty of Tourism and Hospitality Management in Opatija.

Findings - This research examines key factors in creating MCEs for students, who could recall their previous memorable conference experience. Exploratory Factor Analysis was performed first, followed by the hierarchical clustering method and regression analysis to determine significant clusters among participants and their influence on behavioural intention. The results indicate that affectively loyal participants are more likely to show their behavioural intention, in comparison with affectively non-loyal participants.

Contribution - The findings suggest essential implications for the tourism experience theory and for future conference organizing committeeswell.

Keywords: students, memorable conference experience (MCE), hierarchical clustering, and behavioural intentions.
\end{abstract}

\section{INTRODUCTION}

It can be said that business tourism is one of the fastest growing segments of tourism (Rogers, 1998), and its participants are of great importance to the tourism industry (Zhang et al. 2007). Business tourists bring multi-economic benefits to their hosts because they usually stay longer and spend more than other types of tourists when it comes to expenses for accommodation, food and drinks, local transport, and varied consumption (Oppermann and Chon 1997). However, in order to design the best possible offering for this type of tourism, it is important first to define which form of business tourism we are dealing with, that is, whether business tourists are coming to business meetings, incentives, congresses/conferences or exhibitions (Gračan and Rudančić Lugarić 2011).

Out of the above-mentioned types of business tourism, conferences were selected for this study because students are most likely to participate in them. When talking about conferences, it needs to be said that they have unique characteristics which differentiate them from other industries (Chatzigeorgiou et al. 2013), because they incorporate more 
ToSEE - Tourism in Southern and Eastern Europe, Vol. 6, pp. 657-672, 2021.

D. Rašan, M. Laškarin Ažić: MEASURING STUDENTS' MEMORABLE CONFERENCE

products or services, involving the cooperation of various suppliers. The conference program gives its participants the opportunity to follow all the changes in their field of expertise, listen to reputable experts, and learn new skills (Zhang et al. 2007).

In the past, conferences were solely attended by academic experts, but today more and more students are actively or passively taking part in conferences, both in Croatia and around the world. Despite the growing number of students who are becoming conference participants, for the time being there is no empirical research in the literature on the topic of measuring the overall quality of their memorable conference experience (MCE). Taking this into consideration, it is extremely important to research students' preferences as conference participants, because based on their current experiences, insight could be gained on future needs for conferences. In this way, students represent future opinion makers.

So far, studies have mostly aimed at examining the impact of service quality and the satisfaction of conference participants on behavioural intention (Chatzigeorgiou et al. 2013; Dunjic et al. 2012; Haber and Lerner 1999; Samy 2016). Taking into account the lack of studies concerning memorable experience, the aim of this empirical research is to examine and analyse the attitudes of students towards the importance of individual elements needed to attain a high level of overall MCE quality and a high level of behavioural intention depending on cluster affiliation.

Submitted papers are expected to be original contributions and should not be under consideration for any other publication at the same time. They should clearly describe the background of the subject, the author's work, including the methods used, results and concluding discussion on the importance of the paper.

\section{LITERATURE REVIEW}

\subsection{Concept of memorable tourist experience}

The experience economy concept dates back to the 18th century, and in modern times it is perceived as an instrument of maximizing profit/benefit. One of the first philosophers who dealt with this topic was Bentham (1900), who believed that experience represents a positive experience focused on the wellbeing of society in general. Moreover, experiences can be described as "subjective, non-material, continuous and exceptionally personal phenomena" (O'dell 2007, 38), which are based on the cognitive, feelings and expectations (Turner and Bruner 1986). Using the above mentioned as a starting point, the authors believe that in a situation when the client's expectations have been surpassed, the experience will have an affirmative character for the client and will enhance positive emotions. Hence, the experience of an event must contain the so-called wow effect; accordingly, it has to be specific, memorable, and unique (Pine and Gilmore 2011).

Furthermore, with regard to the quality of an experience, it is very important to note that quality differs from one person to another. To be more precise, it is characterized in the scientific literature as "a subjective personal reaction and a feeling that consumers feel during consumption or usage of services" (Otto and Ritchie 1996, 167). This concept can 
ToSEE - Tourism in Southern and Eastern Europe, Vol. 6, pp. 657-672, 2021.

D. Rašan, M. Laškarin Ažić: MEASURING STUDENTS' MEMORABLE CONFERENCE ...

also be defined as a "quest for happiness or wellbeing” (Sharpley and Stone 2012, 225) and in its centre are people, services, and places (Westwood 2006). Among other things, the quality of an experience is perceived as a complex, multidimensional concept, with roots extending to various fields and disciplines within social and natural sciences (Beard and Russ 2017). One of the fields in which this concept has seen exponential market growth is tourism and, therefore, a need has emerged to create and implement experiences intended solely for tourists.

Chan and Baum $(2007,578)$ perceive tourism experience quality as an "affective response from tourists to a desired socio-psychological benefit", with the emphasis being on tourists' emotions. Larsen (2007) in his research determined that a tourist experience is so intense that it is "remembered forever", and according to Csikszentmihalyi (1990), this memorable experience can in the long term contribute to "the feeling of excitement and pleasure that is nurtured for a long time, and a memory of the event becomes a landmark showing what life should look like".

Kim and associates $(2010,638)$ define a memorable tourism experience as a "tourism experience which is positively remembered and which tourists recall after the event". Therefore, the concept of memory is of crucial importance because it includes coding, storing, and locating information (Bettman 1979) and, accordingly, it can be said that memory represents the sole and most important source for the individual during a return visit and spreading word of mouth (Oh et al. 2007).

From the aspect of congress tourism, in order to gain profit, the goal of the business activity holders is to delight the participants of a congress or conference by creating a memorable tourism experience which they will always remember and will pass on to their colleagues. This approach will more likely ensure the possibility of participants coming back to the same conference.

\subsection{Concept of memorable conference experience}

The scientific literature defines congress tourism as travel, the main motivation of which is to actively or passively participate in gatherings or events of diverse character (Geić 2011). The previous scientific literature, however, uses the term business tourism for this type of tourism and the acronym M.I.C.E. is also frequently used.

Business tourism includes the following forms: (a) business meetings, (b) incentives, (c) congresses / conferences, and (d) exhibitions (Gračan and Rudančić Lugarić 2011, 3). Since this study is focused on conferences, special attention will be placed on defining the term.

The term conference comes from the Latin word confere, which means to gather, and from the medieval Latin term conferentia, meaning a meeting or a gathering (Stelten 1995). Anić and associates $(2002,232)$ use the term conference too imply "deliberations, agreement, meeting with the purpose of agreement, discussing an issue or a public speech which normally includes discussion ". 
ToSEE - Tourism in Southern and Eastern Europe, Vol. 6, pp. 657-672, 2021.

D. Rašan, M. Laškarin Ažić: MEASURING STUDENTS' MEMORABLE CONFERENCE ...

According to the Cambridge Dictionary, conference can be defined as an "event which sometimes lasts for a couple of days, and during which a certain topic is discussed", while the Merriam Webster Dictionary (1828) defines it as a "meeting of two or more people to discuss matters of common interest".

Accordingly, the characteristics of a conference are manifested in its limited duration and pre-defined specific goals and tasks, with a frequency of occurrence that can be regular (every six months, annually or perennially) or ad hoc (once and never again).

As a part of the TOMAS research $(2019,34)$ on tourists' attitudes and consumption, the Institute for Tourism focused on the topic of conferences, by conducting a survey on tourist motivations when choosing a destination. The results indicated that after "vacation" (46\%), "business" is a secondary motive for tourist arrivals (4\%), with business tourists deciding on a journey mostly for business meetings (46\%), followed by conferences (18\%), seminars (13\%), team building (5\%), and incentives $(2 \%)$. The analysis showed that more conferences are held in the Adriatic region $(20.4 \%)$ than in the continental part of Croatia (11.6\%), with guests mostly staying in 4- or 5-star hotels (29\%).

The data on the number of conferences show that this number is rising and, in this way, business tourism contributes to the country's economy (Rogers 2015). Due to the outstanding potential of this aspect of tourism for future development, it is important to investigate the guests' preferences, with the goal of satisfying their wishes and needs by ensuring a high-quality memorable experience.

In this context, the quality of a memorable conference experience can be defined as an experience with positive connotations, which stays forever in the memory of the participant, and which is mostly affected by an affordable conference fee, discussions on wider and more specific topics during the conference, conference information which is easily accessible, and a chance for professional development.

\subsection{Measuring the memorable conference experience}

By browsing through databases and looking through scientific literature, it was determined that there are studies which deal with participants' satisfaction with the quality of a held conference (Chatzigeorgiou et al. 2013; Dunjic et al. 2012; Price 1993; Riper et al. 2013; Severt et al. 2007), but not with the quality of memorable experience. Hence, this empirical research is of crucial importance and can serve as a basis for future research.

Price (1993) in his research identifies education, networking, career development, and travelling to desired destinations as principal motivators for attending conferences. According to Severt and associates (2007), those motivators are activities and opportunities, networking, affordability, and educational benefits as well as products and offerings.

The above-mentioned authors created a reliable and valid five-dimensional scale for measuring the level of satisfaction and future behavioural intentions of conference 
ToSEE - Tourism in Southern and Eastern Europe, Vol. 6, pp. 657-672, 2021.

D. Rašan, M. Laškarin Ažić: MEASURING STUDENTS' MEMORABLE CONFERENCE

participants, and their research revealed that educational activities and overall satisfaction have the most significant correlation with future intentions.

Dunjić and associates (2012) conducted a study into the satisfaction of 75 participants of conferences held in Belgrade, Serbia's capital city. Items in their questionnaire referred not only to conference attributes, but also included the elements of a destination, the main reason for doing so being the fact that conference participants represent the final users of a destination's services. Chatzigeorgiou and associates (2013) developed a conceptual model for measuring the quality of services, the quality of the experience, overall satisfaction, and behavioural intentions of conference participants derived from social psychology theory and previous research in the field of marketing. The results of their research confirmed seven out of eight hypotheses, of which only two refer to the quality of the experience. These are: (a) the quality of performance has a positive effect on the quality of participant's experience, and (b) perceived quality of experience with individual aspects has a significant influence on the overall satisfaction of examinees. Also, the study proved a predictive relationship between overall quality of services and satisfaction, and future behavioural intentions of participants, as mentioned in other studies (Chen and Kao 2010; Marković et al. 2015; Murray and Howat 2002; Saha and Theingi 2009; Tomas et al. 2002).

Therefore, professional conference organizers must pay more attention to the way in which the participants perceive their experience (Halim and Mokhtar 2016) as unique and persuasive (Pine and Gilmore 2011), by estimating the conference contents and the participants' future intention of attendance.

Once the importance of creating a conference experience aimed at attracting as many participants as possible was determined, the need to conduct this research emerged. For measuring purposes, a modified model from Riper and associates (2013) was used, encompassing four dimensions: (1) comprehensive characteristics, (2) outdoor activities, (3) conference organizers, and (4) networking.

Further to the above mentioned, this study was guided by the following research aims:

a) to identify key factors for creating MCEs;

b) to identify clusters with regard to affective connection to MCE; and

c) to determine cluster members' behavioural intentions.

\subsection{Loyalty measurement in the experience economy}

The tourism literature recognises several aspects of measuring tourist loyalty, depending on what is being measured and how. The first aspect distinguishes loyalty in two main ways, as behavioural and attitudinal; the second aspect includes ways of expressing loyalty (known as Oliver's (1999) loyalty phases); and the third aspect includes loyalty types such as destination loyalty, event loyalty, and brand loyalty.

Attitudinal loyalty, one of the most commonly used types of loyalty in the tourism literature, is expressed through the intention to repeat and/or recommend (Anton, 
ToSEE - Tourism in Southern and Eastern Europe, Vol. 6, pp. 657-672, 2021.

D. Rašan, M. Laškarin Ažić: MEASURING STUDENTS' MEMORABLE CONFERENCE ...

Camarero and Laguna-Garcia 2014), thus most authors use behavioural intention as a common variable for measuring WOM and intention to repeat. Since behavioural intention has been shown to be the most important antecedent of future behaviour (Lee and Hyun 2016), in many studies both intention to repeat and intention to recommend have been implicitly used as adequate measures for tourist loyalty. On the other hand, behavioural loyalty refers to the number of (re)visits or (re)purchases (Laškarin Ažić, Dlačić and Suštar 2020), which in a tourism context is often combined with attitudinal loyalty, in order to provide a more comprehensive overview of true loyalty.

Concerning loyalty phases, Oliver (1999) believes that consumer attitudinal loyalty may be described through a cognition-affect-connotation pattern. This pattern is described as a sequential process, where through repetitive buying behaviour, consumers first express loyalty in a cognitive sense-intellectual level (comparison of the attributes among different brands available to consumers). In the second phase, consumers develop a feeling of connection (emotional level). Then, on a conative level (behavioural intention level), consumers have a desire to keep visiting the brand or repurchasing the product. On the last level, after being motivated, the consumers' attitude is transformed into action. Although Oliver's loyalty phases provide a useful perception of consumer loyalty development for brands, consumers in the experience economy, where the reason to repurchase is not related to an object but rather to activities, may have a different logic. Since behavioural intentions represent the highest level of attitudinal loyalty, the authors decided to include this level of attitudinal loyalty as the dependent variable in the research model.

Numerous studies have reported the positive effect of satisfaction on behavioural intention, especially at the destination level (Yoon and Uysal 2005; Chen and Chen 2010; Prayag and Ryan 2012) and brand level (Ladhari 2009; Kim, Cho and Han 2014), while few studies have examined the memorable tourist experience and its casual impact on behavioural intentions without using satisfaction as a mediating variable. Among the first to apply this approach were Kim et al. (2010). Their findings confirmed that remembered experience greatly influences behavioural intentions. Since memorable and positive experience implies satisfaction, the authors assumed that this approach would also be applicable to conference participants. Moreover, the authors assumed that participants who have different feelings about memorable conference experience might form different behavioural intentions.

\section{METHODOLOGY}

Primary data obtained by the survey method was used for the purpose of this empirical research, while an online and onsite questionnaire was used as a measuring instrument. Students of the Faculty of Tourism and Hospitality Management were surveyed from 7 - 30 November 2020. The study used a purposive sample, deliberately chosen solely on the basis of convenience and availability of units (Bolšec et al. 2014). The questionnaire consisted of seven parts, with 34 items. The structure of the questionnaire is shown in Table 1. 
ToSEE - Tourism in Southern and Eastern Europe, Vol. 6, pp. 657-672, 2021.

D. Rašan, M. Laškarin Ažić: MEASURING STUDENTS' MEMORABLE CONFERENCE ...

Table 1: Structure of the questionnaire

\begin{tabular}{|c|c|c|}
\hline Parts of the questionnaire & Question types & Measuring scale \\
\hline General conference data & Unstructured questions & $\begin{array}{l}\text { Nominal, ordinal and } \\
\text { proportional scale }\end{array}$ \\
\hline Comprehensive characteristics & Structured questions & $\begin{array}{l}\text { Likert scale of importance } \\
\qquad(1-5)\end{array}$ \\
\hline Outdoor activities & Structured questions & $\begin{array}{l}\text { Likert scale of importance } \\
\qquad(1-5)\end{array}$ \\
\hline Conference organisers & Structured questions & $\begin{array}{l}\text { Likert scale of importance } \\
(1-5)\end{array}$ \\
\hline Networking & Structured questions & $\begin{array}{l}\text { Likert scale of importance } \\
(1-5)\end{array}$ \\
\hline $\begin{array}{l}\text { Overall quality of memorable } \\
\text { experience }\end{array}$ & Structured questions & $\begin{array}{l}\text { Likert scale of importance } \\
(1-5)\end{array}$ \\
\hline
\end{tabular}

The first part of the questionnaire comprised four open-ended questions regarding general conference data pertaining to the conference the students had attended and which surpassed their expectations. Parts 2 to 5 of the questionnaire focused on structured questions, by using a Likert scale of importance with five grades, anchored at one $(1)=$ "not important" and five (5) = "very important". These four parts were designed on the basis of research by Riper and associates (2013). The sixth part of the questionnaire examined the overall quality of the students' memorable conference experience, and the seventh, their behavioural intentions.

Students were asked to grade statements in the sixth and seventh part using a Likert scale of agreement with five grades, anchored at one (1) = "I completely disagree" and five $(5)=$ "I completely agree". The last part of the measuring instrument contained statements relating to the socio-demographic profile of examinees, including their age, gender, name of the faculty, year of studying, student status, frequency of attendance, and motives for attending conferences.

\section{RESULTS}

The sample in total comprised 108 respondents (students), whose answers were later analysed using statistical software SPSS 25.0. To meet the study's objectives the authors applied several different types of analyses, the first being descriptive statistics to present the respondent profile (Table 2). Then, Exploratory Factor Analysis (EFA) was used to identify factors and to analyse the interrelationships among groups of variables, after which, hierarchical cluster analysis and Analysis of variance (ANOVA) were applied to reveal significant clusters. Finally, regression analysis was used to identify key determinants of behavioural intentions. 
ToSEE - Tourism in Southern and Eastern Europe, Vol. 6, pp. 657-672, 2021.

D. Rašan, M. Laškarin Ažić: MEASURING STUDENTS' MEMORABLE CONFERENCE ...

Table 2: Respondent profile $(\mathbf{n}=\mathbf{1 0 8})$

\begin{tabular}{llrr}
\hline Characteristics & & Frequency & Percent \\
\hline Gender & Male & 29 & 26.9 \\
& Female & 79 & 73.1 \\
\hline Year of birth & 1994 & 1 & 0.9 \\
& 1995 & 1 & 0.9 \\
& 1996 & 5 & 4.6 \\
& 1997 & 27 & 21.0 \\
& 1998 & 23 & 40.7 \\
& 1999 & 44 & 6.5 \\
\hline Year of study & 2000 & 7 & 49.1 \\
& 3 & 53 & 21.3 \\
& 4 & 23 & 29.6 \\
\hline Student status & 5 & 32 & 97.2 \\
& Full-time & 105 & 2.8 \\
\hline Frequency of participation in conferences & 1 per year & 3 & 69.4 \\
& $2-3$ per year & 31 & 28.7 \\
\hline
\end{tabular}

Table 2 shows that the number of female respondents surpasses the number of male respondents (79/29). Considering that the respondents are students, their year of birth ranged from 1994 and 2000 (21-27 years old). The majority of respondents are currently $3^{\text {rd }}$ year students $(49.1 \%)$, and most of the respondents are full-time students $(97.2 \%)$ With regard to the frequency of participation, the majority of students tend to participate in conferences once per year $(69.4 \%)$.

Given its exploratory aims, this study first uncovers underlying factors of memorable conference experience by applying Exploratory Factor Analysis. This analysis is in particular useful to reveal significant correlations within explored factors, where a large number of original variables connects into few more representative factors (Stewart, 1981). The obtained results created a set of variables which the authors used to form relationships in the model. The results of Principal Component Analysis (PCA) with the Varimax rotation method (rotated factor matrix) are presented in Table 3.

Table 3: EFA results

\begin{tabular}{lcrrr}
\hline & $\begin{array}{r}\text { Factor } \\
\text { Loading }\end{array}$ & Eigenvalue & $\begin{array}{r}\text { Variance } \\
\text { explained } \\
(\%)\end{array}$ & $\begin{array}{r}\text { Cronbach's } \\
\text { Alpha }\end{array}$ \\
\hline Factor 1: Outdoor activities & & 3.124 & 26.034 & 0.872 \\
\hline $\begin{array}{l}\text { Field trips } \\
\text { Availability of team-building }\end{array}$ & 0.883 & & & \\
activities & 0.878 & & & 0.719 \\
Student parties & 0.876 & & & \\
\hline Factor 2: Networking & & 2.348 & & \\
\hline $\begin{array}{l}\text { Networking opportunities at the } \\
\text { conference }\end{array}$ & 0.813 & & & \\
Opportunities to talk with other & 0.799 & & & \\
conference participants & & & & \\
\hline
\end{tabular}


ToSEE - Tourism in Southern and Eastern Europe, Vol. 6, pp. 657-672, 2021.

D. Rašan, M. Laškarin Ažić: MEASURING STUDENTS' MEMORABLE CONFERENCE ...

Table 3 (continued)

\begin{tabular}{lccrr}
\hline & $\begin{array}{r}\text { Factor } \\
\text { Loading }\end{array}$ & Eigenvalue & $\begin{array}{r}\text { Variance } \\
\text { explained } \\
(\%)\end{array}$ & $\begin{array}{r}\text { Cronbach's } \\
\text { Alpha }\end{array}$ \\
\hline $\begin{array}{l}\text { Opportunities to make new } \\
\text { contacts }\end{array}$ & 0.799 & & & \\
Interactive workshops & 0.521 & & & \\
\hline Factor 3: Behavioural intentions & & 1.617 & 13.476 & 0.792 \\
\hline Recommendation to colleagues & 0.925 & & & \\
$\begin{array}{l}\text { Positive Word of Mouth (WOM) } \\
\text { Revisit intentions }\end{array}$ & 0.902 & & & \\
\hline Factor 4: Quality of lecturers & 0.677 & & & \\
\hline High expertise of lecturers & & 1.248 & 10.403 & \\
Combination of quality lecturers & 0.816 & & & \\
\hline
\end{tabular}

The Kaiser-Mayer-Olkino (KMO) measure was 0.653, higher than the tolerance value of 0.5 , showing a satisfactory measure of sampling adequacy. Bartlett's tests of sphericity $(\mathrm{X} 2=523.781, \mathrm{df}=66$, sig. $=0.000)$ also showed significant results, implying that the authors could proceed with further analysis. Extracted factors explained a total of 69.5 $\%$ of variance, which according to Hair et al. (2014) means that the presented smaller set of variables has a satisfactory level of correlation within factors. Cronbach's alpha used for reliability check ranged from 0.657 and 0.872 . Although Factor 4 is slightly below the required minimum of 0.7 (Baggio and Klobas 2011), the authors decided to keep this factor due to its obvious relevance in exploring key factors for creating MCEs. In addition, the presented results show that out of four factors, three factors explain key elements for creating a memorable conference experience, while one factor explains behavioural intentions.

In order to provide an overview of the attitudinal aspect of loyalty through affective commitment, the authors applied hierarchical cluster analysis. Respondents were grouped based on attachment with their memorable conference experience. In particular, two variables "I feel a special connection to my memorable conference experience", and "I won't forget my positive experience at the conference", measured on a Likert scale (1-5), were applied.

The results of Ward's clustering method provided a two-cluster solution, supported by the criterion of agglomeration coefficient. According to the agglomeration scheme, error reduction is larger between Cluster 1 and Cluster 2 (87,552 errors) than between Cluster 2 and Cluster 3 (39,115 errors), so the authors decided to proceed with the two-cluster solution. The results of the ANOVA test confirm the significance between the two established clusters (Table 4). 
ToSEE - Tourism in Southern and Eastern Europe, Vol. 6, pp. 657-672, 2021.

D. Rašan, M. Laškarin Ažić: MEASURING STUDENTS' MEMORABLE CONFERENCE ...

Table 4: Cluster evaluation - ANOVA results

\begin{tabular}{lccccccc}
\hline & & & & & Std. & \\
& & N & Mean & Std. dev & $\begin{array}{c}\text { Error } \\
\text { Mean }\end{array}$ & F & sig. \\
\hline Connection to & 1 & 83 & 4.63 & 0.487 & 0.053 & 174.668 & 0.000 \\
$\begin{array}{l}\text { memorable conference } \\
\text { experience }\end{array}$ & 2 & 25 & 2.96 & 0.735 & 0.147 & & \\
\hline $\begin{array}{l}\text { Memorability of } \\
\text { positive conference }\end{array}$ & 1 & 83 & 4.53 & 0.549 & 0.060 & 96.207 & 0.000 \\
\begin{tabular}{l} 
experience \\
\hline
\end{tabular} & 25 & 3.02 & 0.909 & 0.182 & & \\
\hline
\end{tabular}

Based on the derived two-cluster solutions, groups were defined as follows:

1) affectively loyal participants - feel a special connection to their MCE and are likely to remember their positive conference experience;

2) affectively non-loyal participants - do not feel a special connection to their MCE and are not quite sure in their memorability of positive experiences.

In order to determine cluster significance with regard to extracted factors, discriminant analysis was conducted (Table 5). Four extracted factors resulted in one canonical discriminant function.

Table 5: Summary of discriminant results

\begin{tabular}{lccccccc}
\hline Function & Eigenvalue & $\begin{array}{c}\text { \% of variance } \\
\text { explained }\end{array}$ & $\begin{array}{c}\text { Canonical } \\
\text { Correlation }\end{array}$ & $\begin{array}{c}\text { Wilk's } \\
\text { lambda }\end{array}$ & $\begin{array}{c}\text { Chi- } \\
\text { square }\end{array}$ & df & sig. \\
\hline 1 & 0.529 & 100 & 0.588 & 0.654 & 44.160 & 4 & 0.000 \\
\hline
\end{tabular}

Wilk's lambda test was used to test the significance of cluster membership for extracted factors. Effect size is measured by canonical correlation $\mathrm{CC}^{2}=0.588$, which means that $58 \%$ of variance is explained in extracted independent variables. Their relevance in predicting cluster memberships is presented in Table 6.

Table 6: Discriminant values for group statistics

\begin{tabular}{lrrrrr}
\hline & Cluster 1 & Cluster 2 & $\begin{array}{r}\text { Wilks' } \\
\text { Lambda }\end{array}$ & F & Sig. \\
\hline F1: Networking & 4.395 & 4.066 & 0.954 & 5.148 & $0.025^{*}$ \\
F2: Outdoor activities & 3.832 & 3.8025 & 0.995 & 0.508 & 0.478 \\
F3: Behavioural intentions & 4.398 & 3.044 & 0.680 & 49.909 & $0.000^{*}$ \\
F4: Quality of lecturers & 4.410 & 4.133 & 0.975 & 2.693 & 0.104 \\
\hline
\end{tabular}

Calculation based on factor mean value; Likert scale (1-5); ${ }^{*} \mathrm{p}<0.05$

The presented results imply that two independent variables "Networking" and "Behavioural intentions" are significant in predicting differences between cluster 1 and cluster 2. Affectively loyal respondents consider "Networking" as being significantly more important in creating MCE than do affectively non-loyal participants. Furthermore, 
ToSEE - Tourism in Southern and Eastern Europe, Vol. 6, pp. 657-672, 2021.

D. Rašan, M. Laškarin Ažić: MEASURING STUDENTS' MEMORABLE CONFERENCE ...

affectively loyal participants are more likely to recommend and revisit the imagined conference, compared with affectively non-loyal participants.

To examine the causal relationship between the established clusters and the behavioural aspect of loyalty, the authors applied OLS regression analysis (Table 7).

\section{Table 7: Behavioural intentions of clusters}

\begin{tabular}{|c|c|c|c|c|c|}
\hline \multirow{2}{*}{ Independent variables } & \multirow{2}{*}{ ß } & \multirow{2}{*}{$\begin{array}{l}\text { Std. } \\
\text { error }\end{array}$} & \multirow{2}{*}{ sig. } & \multicolumn{2}{|c|}{ Collinearity statistics } \\
\hline & & & & Tolerance & VIF \\
\hline Cluster (1.2) & -1.353 & 0.192 & 0.000 & 1.000 & 1.000 \\
\hline
\end{tabular}

$\mathrm{R}^{2}=0.566 \mathrm{~F}(49.909 \mathrm{df}=1), \mathrm{p}<0.00, \beta$ - non-standardized value - equal measurement scale

As presented in Table 7, the results of regression analysis show significant negative relationships between the determined clusters and behavioural intentions. The negative value $(B=-1.353)$ confirms the results of discriminant analysis, whereby affectively loyal respondents have significantly higher intentions to recommend and revisit than do affectively non-loyal participants.

The authors applied discriminant analysis to determine the importance of additional motivations to participate in a conference with regard to cluster membership (Table 8).

Table 8: Summary of discriminant results for motivation variables

\begin{tabular}{cccccccc}
\hline Function & Eigenvalue & $\begin{array}{c}\text { \% of } \\
\text { explained } \\
\text { variance }\end{array}$ & $\begin{array}{c}\text { Canonical } \\
\text { correlation }\end{array}$ & $\begin{array}{c}\text { Wilk's } \\
\text { lambda }\end{array}$ & $\begin{array}{c}\text { Chi- } \\
\text { square }\end{array}$ & df & sig. \\
\hline 1 & 0.515 & 100 & 0.583 & 0.877 & 13.014 & 5 & 0.018 \\
\hline
\end{tabular}

As in the previous discriminant analysis, Wilk's lambda was used to test the significance of cluster membership. According to canonical correlation $\left(\mathrm{CC}^{2}=0.583\right), 58 \%$ of variance is explained with the presented motivations.

Table 9: Discriminant values for group statistics (additional motivations)

\begin{tabular}{lccccc}
\hline Additional motivation & Cluster 1 & Cluster 2 & Wilks' Lambda & F & Sig. \\
\hline Fun & 0.52 & 0.20 & 0.952 & 5.340 & 0.023 \\
New experiences & 0.78 & 0.47 & 0.937 & 7.138 & 0.009 \\
Hanging out with & 0.69 & 0.40 & 0.956 & 4.827 & 0.030 \\
friends/colleagues & & & & & \\
Exploring cultural attractions & 0.44 & 0.07 & 0.930 & 8.036 & 0.005 \\
Exploring nature attractions & 0.28 & 0.07 & 0.971 & 3.156 & 0.039 \\
\hline
\end{tabular}

*Ward's method, 1 - motivation presence, 0 - absence

The presented results of discriminant analysis for additional motivations suggest that affectively loyal participants are significantly more motivated (by all observed motivations) compared with affectively non-loyal participants. The most significant difference between clusters can be seen in the motivations "New experiences" and "Exploring cultural attractions". 
ToSEE - Tourism in Southern and Eastern Europe, Vol. 6, pp. 657-672, 2021.

D. Rašan, M. Laškarin Ažić: MEASURING STUDENTS' MEMORABLE CONFERENCE

\section{CONCLUSION}

In today's experience economy, the tourist experience, one of the most important personal feelings during a tourist's visit, is no longer based on objects, but depends foremost on the personal connection of tourists with the activities they had. Those experiences become very personal and unique, creating engagement on an emotional, physical, mental, or intellectual level (Cornelisse 2018). Kim et al. (2010) argued that measuring tourism satisfaction and the quality of a visit does not sufficiently measure either the degree of memory or the value of a tourism experience, so they developed a new standard for measuring MTE that can provide a better perspective of authentic experiences, and the engagement of tourists towards them. However, as pointed out by some previous authors (Cornelisse 2018), Kim et al. 2010, the scale has a limited ability when applied to specific tourism types. Thus, the authors decided to measure memorable conference experience by applying the scenario approach (recalling memorable conference experiences) and the modified scale for measuring conference experience developed by Riper et al. (2013).

Since previous authors have mainly focused on examining the effect of quality and satisfaction on the behavioural intentions of conference participants (Chatzigeorgiou et al. 2017), one of the prime purposes of this study was to bridge existing gaps by focusing on previous memorable conference experiences and connecting those experiences to behavioural intentions. In particular, the authors explored which factors, with regard to memorable conference experience, are the best predictors of the behavioural intentions of participants to revisit and recommend. Results shows that "Networking", "Outdoor activities", and "Quality of lecturers" are the cornerstones for creating memorable experiences for students when it comes to conferences. Although the results of this study are not fully comparable with previous studies due to the new approach to measuring memorable conference experience, a certain level of alignment still may be found, Namely, this result is partially in line with results reported by Chatzigeorgiou et al. (2017), where quality of performance and quality of experience are directly connected to conference satisfaction. The results also indicate the importance of outdoor activities in creating a memorable conference experience, which was also recognized in some previous studies. According to Beerli and Martin (2004), the more an individual interacts with a visited destination, the more intense the individual's experience of and connection to the destination will be.

Another important finding of this study is that affectively loyal participants and affectively non-loyal participants significantly differ as to their perception of networking for MCE. This means that students who are affectively connected to their memorable conference experience, consider opportunities to connect with other people significantly more important in the creation of MCEs than affectively non-loyal participants. Moreover, of the two established clusters, affectively loyal participants, who will remember positive experiences and feel a strong connection towards positive memories, are more likely to revisit and share positive WOM. This finding is in line with Kim et al. (2010), who reported that individuals are more likely to engage again in those activities that created memorable tourism experiences. Dunjić et al. (2012) found that in order to increase behavioural intention, a conference organising committee first needs to create positive synergy among all destination stakeholders. 
ToSEE - Tourism in Southern and Eastern Europe, Vol. 6, pp. 657-672, 2021.

D. Rašan, M. Laškarin Ažić: MEASURING STUDENTS' MEMORABLE CONFERENCE ...

This study also provides meaningful results, with regard to cluster affiliation, pertaining to additional motivations to participate in a conference that created a memorable positive experience. According to the study's results, affectively loyal participants are generally more motivated by all motives of interest than are affectively non-loyal participants. This means that participants who were driven by additional motivations, such as fun, new experiences, hanging out with friends, and exploring cultural and nature attractions, are also more emotionally attached to their memorable conference experience compared with those participants who were not driven by additional motivations.

Since the findings of this study contribute toward a better understanding of creating a memorable conference experience and of its influence on participants' behaviour in terms of revisit intention and WOM, they are particularly useful for conference organizing committees. This study implies that future organizing committees, seeking to create memorable conference experiences for the student population, should first of all be aware of the possibilities of developing an emotion-driven relationship with students. Since students, with whom such a relationship has been formed, show significantly greater intentions to revisit and recommend, conference organizing committees should attach special attention to key elements of creating memorable conference experiences (networking) and to additional motivations to participate in conferences (to have fun, new experiences, hang out with friends, and explore cultural and nature attractions).

Despite its significant contribution to the tourism experience literature, this study has several limitations that should be addressed. First, as the small sample size and focus on only the student population might influence the generalization of results, researchers should keep in mind that the presented results have an indicative purpose. Second, since the research was conducted in an extremely changing environment due to the coronavirus and lockdowns, research was initially conducted onsite but then later in an online environment after lockdown measures were implemented. Since this study is limited with regard to comparing results concerning nationality and field of study, it is advisable that further research on this topic should also include students with different study interests and in a broader geographic area.

\section{REFERENCES}

Andersson, T.D. (2007), „The Tourist in the Experience Economy “, Scandinavian Journal of Hospitality and Tourism, Vol. 7, No. 1, pp. 46-58. https://doi.org/10.1080/15022250701224035

Anić, Š., Klaić, N., ans Domović, Ž. (2002), Rječnik stranih riječi-Tuđice, posuđenice, izrazi, kratice i fraze, Sani-plus, Zagreb.

Antón, C., Camarero, C. and Laguna-Garcia, M. (2017), "Towards a new approach of destination loyalty drivers: Satisfaction, visit intensity and tourist motivations", Current Issues in Tourism, Vol. 20, No. 3, pp. 238-260. https://doi.org/10.1080/13683500.2014.936834

Baggio, R. and Klobas, J. (2011), Quantitative methods in tourism: A handbook, Channel View Publications, Bristol.

Beard, C. and Russ, W. (2017), "Event evaluation and design: Human experience mapping", Event Management, Vol. 21, No. 3, pp. 365-374. https://doi.org/10.3727/152599517X14942648527563

Beerli, A. and Martín, J.D. (2004), "Tourists' characteristics and the perceived image of tourist destinations: a quantitative analysis - a case study of Lanzarote, Spain", Tourism management, Vol. 25, No. 5, pp. 623-636. https://doi.org/10.1016/j.tourman.2003.06.004 
ToSEE - Tourism in Southern and Eastern Europe, Vol. 6, pp. 657-672, 2021.

D. Rašan, M. Laškarin Ažić: MEASURING STUDENTS' MEMORABLE CONFERENCE ...

Bettman, J.R. (1979), "Memory factors in consumer choice: A review", Journal of Marketing, Vol. 43, No. 2 , pp. 37-53. https://doi.org/10.1177/002224297904300205

Bolšec, K., Safarić, M. and David, V. (2014), "Method of sample and standard HRN ISO 2859-1", Technical Journal, Vol. 8, No. 3, pp. 214-221.

Lian Chan, J.K. and Baum, T. (2007), "Percepcija ekoturista o iskustvu u ekoturizmu u donjem Kinabatanganu, Sabahu, Malezija", Časopis održivog turizma, Vol. 15, No. 5., pp. 574-590. https://doi.org/10.2167/jost679.0

Cambridge Dictionary (nd.) Conference, in Cambridge Dictionary (online), viewed 2 November 2020, https://dictionary.cambridge.org/dictionary/english/conference

Chatzigeorgiou, C., Christou, E. and Simeli, I. (2017), "Delegate satisfaction from conference service quality and its impact on future behavioural intentions", in Proceedings of ICCMI 2017, Thessaloniki, Greece, 21-23 June 2017, Alexander Technological Institute of Thessaloniki, Thessaloniki, pp. 532-544.

Chen, C.F. and Kao, Y.L. (2010), "Relationships between process quality, outcome quality, satisfaction, and behavioural intentions for online travel agencies-evidence from Taiwan", The Service Industries Journal, Vol. 30, No. 12, pp. 2081-2092. https://doi.org/10.1080/02642060903191108

Chen, C.F. and Chen, F.S. (2010), "Experience quality, perceived value, satisfaction and behavioral intentions for heritage tourists", Tourism management, Vol. 31, No. 1, pp. 29-35. https://doi.org/10.1016/j.tourman.2009.02.008

Cornelisse, M. (2018), "Understanding memorable tourism experiences: A case study", Research in Hospitality Management, Vol. 8, No. 2, pp. 93-99. https://doi.org/10.1080/22243534.2018.1553370

Csikszentmihalyi, M. (1990), Flow: The psychology of optimal experience-steps toward enhancing the quality of life, Harper Perennial Modern Classics, New York.

Dunjic, J., Dragicevic, V., Arsenovic, D., Pantelic, M. and Stankov, U. (2012), "Conference attendees' satisfaction: Evidence from Belgrade (Serbia)", Turizam, Vol. 16, No. 4, pp. 170-179.

Geić, S. (2011), Menadžment selektivnih oblika turizma, Sveučilište u Splitu, Split.

Gračan, D. and Rudančić Lugarić, A. (2011), "Business tourism-Modern form for improvement of the competitiveness of Croatian tourism", Ekonomska misao i praksa, Vol. 5, No. 2, pp. 579-590.

Haber, S. and Lerner, M. (1999), "Correlates of Tourist Satisfaction", Annals of Tourism Research, Vol. 26, No. 1, pp. 191-201. https://doi.org/10.1016/S0160-7383(98)00060-7

Hair, J., Black, W., Babin, B. and Anderson, R. (2014), Multivariate Data Analysis, Pearson Education Limited, London.

Halim, A.H.A. and Mokhtar, A.R.M. (2016), "Creating memorable visitor experiences by assessing the satisfaction level and behavioural consequences of attendees", Procedia Economics and Finance, Vol. 37, pp. 1-6. https://doi.org/10.1016/S2212-5671(16)30084-3

Han, H., Lee, J.S., Trang, H.L. and Kim, W. (2018), "Water conservation and waste reduction management for increasing guest loyalty and green hotel practices", International Journal of Hospitality Management, Vol. 7, No. 5, pp. 58-66. https://doi.org/10.1016/j.ijhm.2018.03.012

Kim, Y., Cho, M., and Han, H. (2014), "Testing the Model of Hotel Chain Frequency Program Members' Loyalty Intentions", Asia Pacific Journal of Tourism Research, Vol. 19, No. 1, pp. 35-60. https://doi.org/10.1080/10941665.2012.724019

Kim, J.-H., Ritchie, J. and Tung, V. (2010), "The effect of memorable experience on behavioral intentions in tourism: A structural equation modeling approach", Tourism Analysis, Vol. 15, No. 6, pp. 637-648. https://doi.org/10.3727/108354210X12904412049776

Ladhari, R. (2009), "Service quality, emotional satisfaction, and behavioural intentions", Managing Service Quality: An International Journal, Vol. 19, No. 3, pp. 308-331. https://doi.org/10.1108/09604520910955320

Larsen, S. (2007), "Aspects of a psychology of the tourist experience", Journal of Hospitality and Tourism, Vol. 7, No. 1, pp. 7-18. https://doi.org/10.1080/15022250701226014

Laškarin Ažić, M., Dlačić, J. and Suštar, N. (2020), "Loyalty Trends and Issues in Tourism Research", Tourism and Hospitality Management, Vol. 26, No. 1, pp. 133-155. https://doi.org/10.20867/thm.26.1.8

Lee, K. and Hyun, S. (2016), "The Effects of Perceived Destination Ability and Destination Brand Love on Tourists' Loyalty to Post-Disaster Tourism Destinations: The Case of Korean Tourists to Japan", Journal of Travel and Tourism Marketing, Vol. 33, No. 5, pp. 613-627. https://doi.org/10.1080/10548408.2016.1167349

Marković, S., Dorčić, J. and Krnetić, M. (2018), "The influence of perceived quality on emotions and behavioral intentions in restaurants: Application of PLS-SEM", in Proceedings of 24th CROMAR Congress: Marketing theory and practice-building bridges and fostering collaboration, pp. 55-69.

Marušić, Z., Čorak, S., Ivandić, N., Beroš, I. and Ambrušec, I. (2019), Stavovi i potrošnja turista u HrvatskojTOMAS istraživanje, Institut za turizam, Zagreb. 
ToSEE - Tourism in Southern and Eastern Europe, Vol. 6, pp. 657-672, 2021.

D. Rašan, M. Laškarin Ažić: MEASURING STUDENTS' MEMORABLE CONFERENCE ...

Murray, D. and Howat, G. (2002), "The relationships among service quality, value, satisfaction, and future intentions of customers at an Australian sports and leisure centre", Sport Management Review, Vol. 5, No 1, pp. 25-43. https://doi.org/10.1016/S1441-3523(02)70060-0

O'dell, T. (2007), "Tourist experiences and academic junctures", Scandinavian Journal of Hospitality and Tourism, Vol. 7, No. 1, pp. 34-45. https://doi.org/10.1080/15022250701224001

Oh, H., Fiore, A.M. and Jeoung, M. (2007), "Measuring experience economy concepts: Tourism applications", Journal of travel research, Vol. 46, No. 2, pp. 119-132. https://doi.org/10.1177/0047287507304039

Oppermann, M. and Chon, K.S. (1997), "Convention participation decision-making process", Annals of tourism Research, Vol. 24, No. 1, pp. 178-191. https://doi.org/10.1016/S0160-7383(96)00049-7

Otto, J.E. and Ritchie, J.B. (1996), "The service experience in tourism", Tourism management, Vol. 17, No. 3 , pp. 165-174. https://doi.org/10.1016/0261-5177(96)00003-9

Pine, B.J.I. and Gilmore, J.H. (2011), The Experience Economy, Updated Edition, Harvard Business Review Press, Brighton.

Prayag, G. and Ryan, C. (2012), "Antecedents of tourists' loyalty to mauritius: The role and influence of destination image, place attachment, personal involvement, and satisfaction", Journal of Travel Research, Vol. 5, No. 3, pp. 342-356.

Price, C. (1993), An empirical study of the value of professional association meetings from the perspective of attendees, PhD thesis, Virginia Polytechnic and State University, Virginia.

Raspor, S. (2012), Multivarijatna statistička analiza zadovoljstva klijenata u hotelskoj industriji [in Croatian], Phd thesis, Faculty of tourism and hospitality management, Opatija.

Riper, C., Riper, C., Kyle, G.T. and Lee, M.E. (2013), "Understanding how social networking influences perceived satisfaction with conference experiences", Annals of Leisure Research, Vol. 16, No. 1, pp. 104-114.

Rogers, T. and Davidson, R. (2015), Marketing destinations and venues for conferences, conventions and business events, Routledge, London.

Rogers, T. (1998), Conference: A twenty-first century industry, Addison Wesley Longman Publishing, Boston.

Saha, G.C. and Theingi. (2009), "Service quality, satisfaction, and behavioural intentions", Managing Service Quality: An International Journal, Vol. 19, No. 3, pp. 350-372. https://doi.org/10.1108/09604520910955348

Samy, H. (2016), "Exploring factors that influence domestic tourists' satisfaction with budget hotel services in Egypt", Journal of Tourism, Heritage \& Services Marketing, Vol. 2, No. 2, pp. 17-22. https://doi.org/10.5281/zenodo.376344

Severt, D., Wang, Y., Chen, P.-J. and Breiter, D. (2007), "Examining the motivation, perceived performance, and behavioral intentions of convention attendees: Evidence from a regional conference", Tourism Management, Vol. 28, No. 1, pp. 399-408. https://doi.org/10.1016/j.tourman.2006.04.003

Sharpley, R. and Stone, P. (2012), Contemporary tourist experience: concepts and consequence, Routledge, London.

Stelten, L.F. (1995), Rječnik Ecclesa. Latinski, Hendrickson Publishers, Peabody.

Stewart, D.W. (1981), "The application and misapplication of factor analysis in marketing research", Journal of marketing research, Vol. 18, No. 1, pp. 51-62. https://doi.org/10.1177/002224378101800105

Tomas, S., Scott, D. and Crompton, J. (2002), "An investigation of the relationships between quality of service performance, benefits sought, satisfaction and future intention to visit among visitors to a zoo", Managing Leisure, Vol. 7, No. 4, pp. 239-250. https://doi.org/10.1080/136067102100005589

Turner, V.W. and Bruner, E.M. (1986), The Anthropology of experience, University of Illinois press, Chicago.

Merriam-Webster Dictionary (nd.) Conference, in Merriam-Webster Dictionary (online), viewed 2 November 2020, https://www.merriam-webster.com/dictionary/conference

Westwood, S. (2006), "Shopping in sanitised and un-sanitised spaces: Adding value to tourist experiences", Journal of Retail \& Leisure Property, Vol. 5, No. 4, pp. 281-291. https://doi.org/10.1057/palgrave.rlp.5100033

Yoon, Y. and Uysal, M. (2005), "An examination of the effects of motivation and satisfaction on destination loyalty: a structural model", Tourism management, Vol. 26, No. 1, pp. 45-56.

Zhang, H.Q., Leung, V., and Qu, H. (2007), "A refined model of factors affecting convention participation decision-making", Tourism Management, Vol. 28, No. 4, pp. 1123-1127. https://doi.org/10.1016/j.tourman.2006.07.008 
ToSEE - Tourism in Southern and Eastern Europe, Vol. 6, pp. 657-672, 2021.

D. Rašan, M. Laškarin Ažić: MEASURING STUDENTS' MEMORABLE CONFERENCE ...

Dora Rašan, Student

University or Rijeka, Faculty of Tourism and Hospitality Management Primorska 46, 51410 Opatija, Croatia

dora.rasan1996@gmail.com

Marina Laškarin Ažić, $\mathrm{PhD}$, Assistant Professor

University or Rijeka, Faculty of Tourism and Hospitality Management

Department of Hospitality

Primorska 46, 51410 Opatija, Croatia

marinal@fthm.hr 